\title{
Appetite suppressants and pulmonary hypertension
}

\author{
N F Voelkel \\ Pulmonary Hypertension Center, University of Colorado Health Sciences Center, \\ Denver, Colorado, USA
}

Introductory article

Appetite-suppressant drugs and the risk of primary pulmonary hypertension

L Abenhaim, Y Moride, F Brenot, S Rich, J Binichou, X Kurz, T Higenbottam, C Oakley, E Wouters, M Aubier, G Simonneau, B Begaud for the International Primary Pulmonary Hypertension Study Group

Background. Recently in France, primary pulmonary hypertension developed in a cluster of patients exposed to derivatives of fenfluramine in appetite suppressants (anorexic agents), which are used for weight control. We investigated the potential role of anorexic agents and other suspected risk factors for primary pulmonary hypertension. Methods. In a case-control study, we assessed 95 patients with primary pulmonary hypertension from 35 centers in France, Belgium, the United Kingdom, and the Netherlands and 355 controls recruited from general practices and matched to the patients' sex and age. Results. The use of anorexic drugs (mainly derivatives of fenfluramine) was associated with an increased risk of primary pulmonary hypertension (odds ratio with any anorexic-drug use, 6.3; 95 percent confidence interval, 3.0 to 13.2). For the use of anorexic agents in the preceding year, the odds ratio was 10.1 (95 percent confidence interval, 3.4 to 29.9). When anorexic drugs were used for a total of more than three months, the odds ratio was 23.1 (95 percent confidence interval, 6.9 to 77.7). We also confirmed an association with several previously identified risk factors: a family history of pulmonary hypertension, infection with the human immunodeficiency virus, cirrhosis, and use of cocaine or intravenous drugs. Conclusions. The use of anorexic drugs was associated with the development of primary pulmonary hypertension. Active surveillance for this disease should be considered, particularly since the use of anorexic drugs is expected to increase in the near future. (N Engl J Med 1996;335: 609-16)

Primary pulmonary hypertension (PPH), also called unexplained pulmonary hypertension, is a rare disease with at least three different recognised histological presentations, ${ }^{1}$ of which the so-called plexogenic arteriopathy is the most commonly encountered. The disease occurs with a predominance in young women, but incidence peaks have been noted also in children and in a geriatric population. ${ }^{2} \mathrm{PPH}$ is clinically characterised by non-specific symptoms of dyspnoea or cough and therefore is quite often initially misdiagnosed. Occasionally the first clinical presentation is with signs of right heart failure. The median survival after diagnosis of PPH has been estimated to be 2.8 years. $^{3}$ Thus, in many patients the disease takes a rapidly progressive very malignant course.

In recent years associations of plexogenic pulmonary arteriopathy have been found with portal hypertension ${ }^{45}$ and with AIDS. ${ }^{6}$ Until 1993 when Brenot and coworkers ${ }^{7}$ published their observations entitled Primary pulmonary hypertension and fenfluramineuse, the historical context of appetite depressants and their possible role as pulmonary hypertension-inducing drugs had been nearly forgotten. This was particularly apparent in a number of contemporary reviews of pulmonary artery hypertension where the potential aetiological role of anorexigens was not mentioned. ${ }^{8}$

The introductory article ${ }^{10}$ reminds us that there is a recognised association between the intake of certain appetite-suppressant drugs and the development of $\mathrm{PPH} .{ }^{11}$

As stated, $\mathrm{PPH}$ is a rare disease and its incidence in any population group where an unusually high prevalence has been established - for example, in patients with liver cirrhosis and portal hypertension or patients with AIDS - is still rather small. The most likely explanation is a low prevalence of a "pulmonary hypertension gene" or of a constellation of genetic factors. Given such a low prevalence of genetic predisposition, any trigger or expression factor will raise the number of patients with PPH to only a small extent. The introductory article by Abenhaim et al describes the first prospective study which attempts to estimate the relative risk for the development of PPH from anorexigen use Prior to this multinational European study there had 
been isolated case reports which strongly indicated that anorexigen intake can be associated causally with PPH . $\mathrm{U}$ sually such association can be claimed when a patient develops unexplained pulmonary hypertension in close temporal relation to anorexigen use and when no other drugs are involved Analysis of th drugs are invo the primary pulmonary hypertension registry of the U S $\mathrm{N}$ ational Institutes of $\mathrm{H}$ ealth ${ }^{3}$ showed that $5 \%$ of the patients with PPH had a history of anorexigen use, and B renot et al ${ }^{7}$ found that, among their 125 cases of $\mathrm{PPH}$, $14 \%$ had a history of anorexigen use $(25 \%$ of all their female patients). Based on these data, it is not likely that anorexigen use is currently the overwhelming cause of PPH but if anorexigen use continues to increase it is likely to become an incre is likely to become an increasingly important cause of $\mathrm{PPH}$

F or the prospective International Primary Pulmonary $\mathrm{H}$ ypertension Study (IPPHS) Group, 35 centres in $\mathrm{F}$ rance, Belgium, the $\mathrm{N}$ etherlands, and the $U \mathrm{~K}$ agreed to participate and to report cases of PPH diagnosed between September 1992 and September 1994. A tota of 95 patients with PPH were identified, 64 of whom had been reporter wentres. Definite use of anorexigens had been reported by 30 of the 95 patients with PPH but by only 26 of 355 controls. Although the study was international in design, the data largely represented the $\mathrm{F}$ rench experience. Perhaps the most striking finding of the IPPH S was that roughly $12 \%$ of the patients with $\mathrm{PPH}$ had taken anorexigens for 12 months or longer (compared with $0.6 \%$ in the control group). ${ }^{10}$

\section{Anorexigens and PPH: the historical context}

Several medical centres in Switzerland, Austria, and Germany registered an increased incidence of severe pulmonary hypertension beginning in 1967, ${ }^{12-17}$ roughly 18 months after the anorexigen $M$ enocil (aminorex fumarate) had been released in these three countries; by 1970150 cases of PPH associated with aminorex by 1970150 cases of $\mathrm{PPH}$ associated with aminorex
use had been reported. ${ }^{17} \mathrm{~T}$ he 1985 review by Gurtner ${ }^{18}$ use had been reported. ${ }^{17}$ The 1985 review by G urtner
concluded that altogether 582 cases of aminorexinduced PPH had been reported. The early experience with this epidemic in Vienna (fig 1) illustrates the latency period between the time of introduction of the drug and the time when an increased incidence of PPH was (the drug had been released in December 1965). Although the drug was taken off the market in

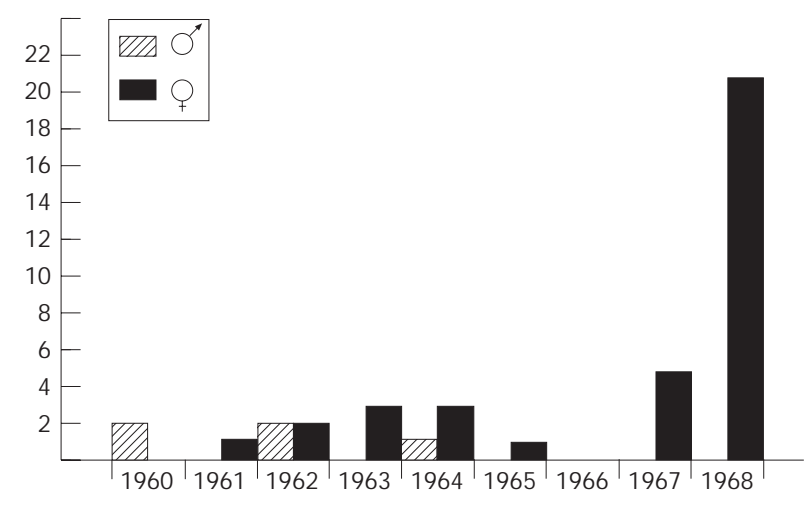

Figure 1 Graph showing the increase in the incidence of primary pulmonary hypertension (particularly in women) with a latency period following introduction of the appetite suppressant aminorex in December 1965 . The drug with permission from reference 15 .

\begin{tabular}{|ll}
$\begin{array}{l}\text { History of drug-induced primary pulmonary } \\
\text { hypertension (PPH) }\end{array}$ \\
Aminorex released & D ecember 1965 \\
F irst reports of aminorex-PPH & G urtner (1968) \\
& K aindl (1969) \\
Report on 21 aminorex-PPH & G ahl (1970) \\
patients & \\
E pidemiology of aminorex-PPH & G urtner (1970) \\
F irst report of fenfluramine-PPH & D ouglas (1981) \\
Aminorex-PPH revisited; report on & G urtner (1985) \\
582 cases & B renot (1993) \\
F enfluramine retrospective data & B rent \\
D exfenfluramine prospective study & Abenhaim (1996)
\end{tabular}

N ovember 1968, cases of aminorex-induced PPH were diagnosed for several years thereafter (box). ${ }^{1718}$

Symptoms consistent with PPH occurred 9-14 months after the start of the aminorex treatment, approximately one per 1000 aminorex users developed $\mathrm{PPH}$, and the lesions of aminorex-induced PPH were histologically indistinguishable from those recognised in sporadic cases of PPH. ${ }^{101819} \mathrm{G} \mathrm{urtner}^{18}$ followed 71 patients with aminorex-induced PPH and found that 34 patients had died (with a median survival of 3.5 years). There was no clearcut relationship between the amount of the drug taken and mortality, but the risk of developing aminorex-induced PPH increased with increased drugintake ${ }^{2021}$ Attempts to induce pulmonary hypertension by feeding amino hypertension by feeding aminorex to rodents, dogs, and cattle ${ }^{1922-24}$ failed, which would not be surprising if there is a specific human genetic susceptibility. The retrospective data analysis of the aminorex epidemic also showed that approximately $10 \%$ of the patients with PPH had used aminorex in combination with chlorphentermine, phenmetracine, or amphetamine. ${ }^{18}$ Since the aminorex epidemic, sporadic cases of PPH related to the use of fenfluramine or phenformin have been reported. ${ }^{25}$

\section{Anorexigen-associated pulmonary hypertension:} the pharmacological context

The exact pathogenetic events leading to the manifestation of PPH are still unknown. It appears, however, that for the anorexigen-associated cases of PPH, 5hydroxytryptamine (5-HT, serotonin) might be a common denominator. Figure 2 shows the structures of some of the anorexigens, including aminorex, and also the frequently used antidepressant agents such as sertraline hydrochloride and fluoxetine hydrochloride. All of these agents release $5-\mathrm{H}$ T from storage sites or inhibit uptake of 5-HT, or both. Although aminorex resembles amphetamine and has been adrenaline (norepinephrine), aminorex also releases 5 HT. Gahl and coworkers ${ }^{14}$ found no increase in levels of metabolites of 5-HT in the urine of patients with aminorex-induced PPH. H owever, these measurements were conducted many months after the aminorex intake. $\mathrm{N}$ evertheless, a unifying hypothesis operating with a 5HT paradigm may be justified at the present time.

$\mathrm{H}$ erve and coworkers reported the case history of a patient with PPH and a platelet storage disorder ${ }^{26}$ and more recently, described the plasma 5-HT levels in patients with $\mathrm{PPH} .{ }^{27} \mathrm{Of}$ great interest is their finding that, in their patients with PPH (some of whom had taken anorexigens), there was an increase in plasma 5$\mathrm{HT}$ levels and an increased release of $5-\mathrm{HT}$ from the platelets. M oreover, this increase in plasma levels of 5- 


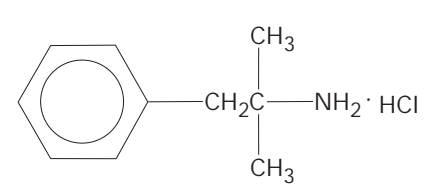

Phentermine hydrochloride

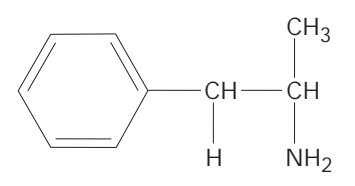

Amphetamine

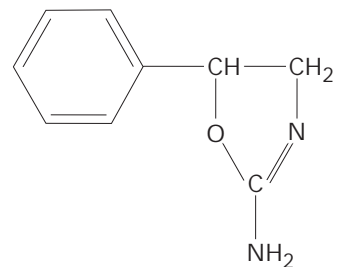

Aminorex
$\overbrace{\mathrm{CH}_{3}}^{\mathrm{CF}_{3}}{ }_{\mathrm{CH}}^{\mathrm{CH}_{2}} \mathrm{CH}_{3} \cdot \mathrm{HCl}$

Dexfenfluramine hydrochloride

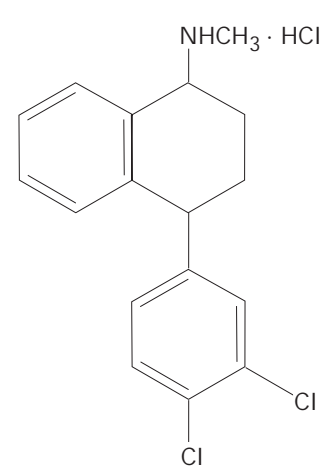

Sertraline hydrochloride

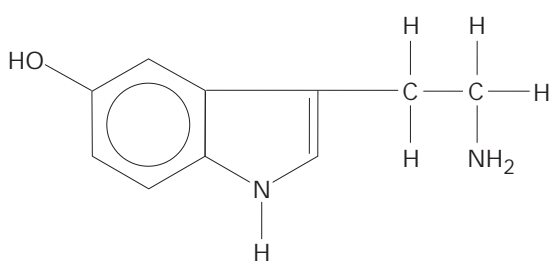

5-Hydroxytryptamine

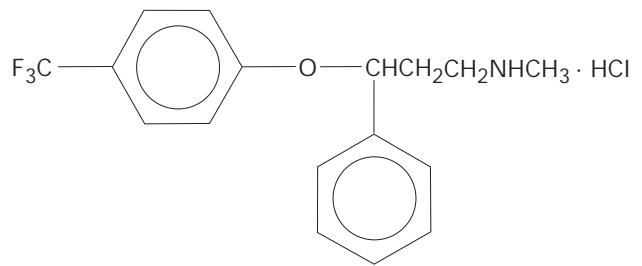

Fluoxetine hydrochlorid

Figure 2 Chemical structures of 5-hydroxytryptamine (5-HT, serotonin) and 5-HT-releasing appetite suppressants or antidepressants.

$\mathrm{HT}$ persisted in those patients who had received lung transplantation. If this finding of raised levels of 5 $\mathrm{HT}$ in patients with PPH can be confirmed in other populations with PPH, it would betempting to speculate that agents which alter the metabolism of $5-\mathrm{H} \mathrm{T}$ could be trigger factors for PPH (figs 3 and 4).

It is clear from experimental data that 5-HT does, indeed, cause pulmonary vasoconstriction ${ }^{28}$ and produces both hyperplasia and hypertrophy of isolated
cultured pulmonary artery smooth muscle cells. ${ }^{29} 30 \mathrm{~T}$ his cultured pulmonary artery smooth muscle cells.
proliferative effect of $5-\mathrm{HT}$ is apparently transduced through the 5-HT2 receptor. $^{30}$ However, the relationship between alteration in 5-H T metabolism and

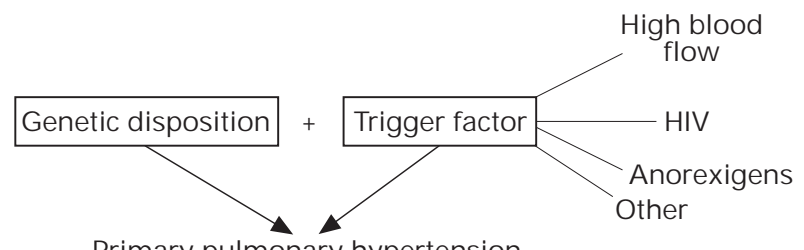

Figure 3 Scheme depicting the confluence of a presently ill described g development of primary pulmonary hypertension. It is clear that the trigger factors are of a vastly varied nature, infections, and anorexigens.
$\mathrm{PPH}$ is probably more complex, as evidenced by the absence of reports of a relationship between the chronic intake of antidepressants such as fluoxetine hydrochloride (a very widely used drug) and PPH. H owever, in our centre we have recently diagnosed $\mathrm{PPH}$ in a woman who had not taken anorexigens but had been treated for her depression with sertraline hydrochloride (unpublished observation).

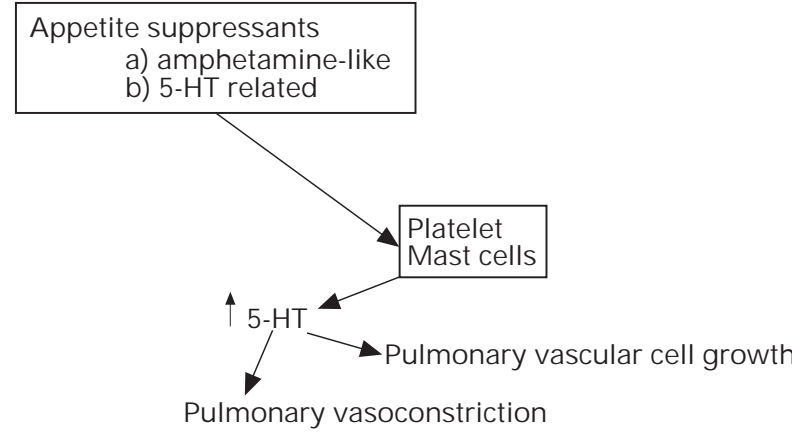

Figure 4 Scheme depicting a hypothetical sequence of metabolism of 5-hydrite suppressants which alter the of 5-HT from platelets and mast cells. In susceptible individuals - that is, those with a genetic disposition increased levels of 5 -HT could both alter pulmonary vascular
tone and also affect pulmonary vascular cell growth. 
LEARNING POINTS

* Appetite suppressants which affect the release or uptake of 5-HT (serotonin) may be trigger factors for primary pulmonary hypertension (PPH) in a genetically susceptible segment of the general population.

* Primary pulmonary hypertension is a generally fatal disease of young women, a group more likely to take appetite suppressants than men.

* There may or may not be an association between obesity itself and the development of PPH but PPH does occur in non-morbidly obese users of appetite suppressants.

* Development of dyspnoea, fatigue and cough in anorexigen users (particularly when these symptoms occur in spite of w eight loss) is a reason for alarm and should trigger investigation for pulmonary hypertension.

\section{Anorexigen-associated pulmonary hypertension} and obesity: risk-benefit ratio

It should be clear from the above that anorexigens can cause pulmonary hypertension. It should also be appreciated that many patients are looking for a pharmacological solution to their obesity problem. In the USA dieting and weight management are a multibillion
dollar industry. $\mathrm{H}$ undreds of new diet pill clinics have opened during the last year. Presently we have no good understanding of the relationship between body weight and pulmonary hypertension - apart from the well known association of the obesity/hypoventilation/polycythaemia syndrome and pulmonary hypertension.

Gurtner, summarising his experience of 71 patients Gurtner, summarising his experience of 71 patients
with presumed anorexigen-induced $\mathrm{PPH},{ }^{18}$ found that $50 \%$ of the patients had used aminorex while being only mildly overweight ( $110 \%$ of ideal body weight). While the normal incidence of PPH is about 1.2 cases per one million population/year, the risk of developing $\mathrm{PPH}$ for non-overweight users of dexfenfluramine has been estimated at 28 per million/year, and that for overweight users at 55 per million/year. ${ }^{32}$ T his implies that obesity might be a co-factor for the development of PPH, but might be a co-factor for the development of PPH, but
there is much controversy as to whether obesity is there is much controversy as to whether obesity is
independently related to PPH. TheIPPHS data indicate independently related to $\mathrm{PPH}$. The PPH S data indicate mass index of $\geq 30$ compared with only $18.3 \%$ in the control group (the controls having been matched with the cases for age and sex only). The difference is probably explained by obese women being more likely to use anorexigens and the authors concluded that the effect of anorexigen intake on PPH "was the same whether patients had a high body mass index or not". ${ }^{10}$ H owever, obese patients are not infrequently depressed and they may also be hypoxaemic; it is not known whether hypoxaemia or the concomitant use of antifor PPH. Experiments in dogs have shown an increase in pulmonary vascular resistance with a combination of hypoxaemia and dexfenfluramine administration. ${ }^{33}$

In 1996 about 10 million prescriptions for phentermine, more than six million prescriptions for fenfluramine (total sales $\$ 190$ million in 1996), and approximately 2.5 million prescriptions for dexfenfluramine were written in the USA. Whereas the profit margins for the diet pill clinics are apparently greater than those in the restaurant business, little concern is being expressed about the prospects of successful long term weight loss. Little is known from clinical studies about the efficacy of any of the currently prescribed anorexigens, ${ }^{34}$ but Weight Watchers International has advised that "people will take the drug for as long as they need to achieve their weight loss goal and they should continue to take the drug to maintain their weight loss" (M ay 1996).

All this is worrisome when one considers that the pharmaceutical industry does not generally screen new compounds for their potential to cause pulmonary hypertension. By contrast, drugs do not usually reach the market if they raise the systemic blood pressure. Given the uncertainty of currently available "diet pills" to cause successful long term weight loss 253435 and the risk of developing a lethal disease, the risk-benefit ratio ductory article has lessened previous uncertainty and ductory article has lessened previous uncertainty and as the number of anorexigen users in the USA approaches 20 million, we may soon witness a much greater incidence of PPH in that country as in Europe, anywhere from 400 to 1000 additional new cases of PPH per year.

$1 \mathrm{~K}$ ay JM. The pathology of primary pulmonary hypertension. Semin 2 Phipps B, Wong B, C Chang J, D unn M. Unexplained severe pulmonary hypertension in the older age group. Chest 1983; 84:399-402.
D'Alonzo GE, Barst RI, Ayers SM, Bergofsky EH, Brundage BH, Detre $\mathrm{KM}$, et al. Survival in patients with primary pulmonary hypertension. Ann Intern M ed 1991; 115:343-9.

4 Lebrec D, Capron J J-P, D humeaux D, Benhamou J-P. Pulmonary hyper120.849-56

$5 \mathrm{M}$ CD onnell $\mathrm{PJ}$, Toye PA, H utchins $\mathrm{G}$. Primary pulmonary hypertension and cirrhosis: are they related? Am Rev Respir D is 1983;127:437-41. and the human immunodeficiency virus. A rch Intern M ed 1995; 155:

7 Brenot $F$, Herve P, Petipretz $P$, Parent $F$, D uroux P, Simonneau $G$. 1993;70.537-41.

8 Weissman N N, Fuster V. Diagnosis of pulmonary artery hypertension. Rounds S Hill N S. Pulmonary hypertensive diseases Chest 1984:86 397-405. A benhaim $L, M$ oride $L, B$ renot $F$, Rich $S$, Benichou J, Kurz X, et
al. Appetite-suppressant drugs and the risk of primary pulmonary Reeves IT Voekel NF. Primary umonary hypertension. In: M oser K ed. Lung biology in health and disease. Vol 14. N ew York: M arce Durtner H P, G ertsch M, Salzmann C, Scherrer M, Stucki P, Wyss F. Häufen sich die primär vasculären F Frmen des chronischen Cor
pulmonale? Schweiz M ed Wochenschr 1968;98:1579-1695. pulmonale? Schwelz
voss $\mathrm{H}, \mathrm{H}$ arms $\mathrm{H}$. E pidemiology and clinical aspects of primary vascular pulmonary hy

$14 \mathrm{G}$ ahi VK, Fabel H, G reiser E, Harmjanz D, O stertag H, St Stender H. Primary vascular pulmonary hypertension. A report on 21 cases. $Z$ $15 \mathrm{~K}$ aindl VF. Primare pulmonale hypertension. Wien Z Inn M ed 1969;50 16 Schwingshackl H, Amor H, Dienstl F. Primäre pulmonale hypertonic bei sieben jüngeren Frauen. D tsch Med Wochenschr 1969;94639-45. $\mathrm{G}$ ahl VK, Fabel $\mathrm{H}$, G reiser $\mathrm{E}, \mathrm{H}$ armjanz $\mathrm{D}$, O Stertag $\mathrm{H}$, St Stender $\mathrm{H}$.
Primäre vaskuăre pulmonale H ypertonie. Z K reislaufforsch 1970;59. 868-8

P. Chronische pulmonale $\mathrm{H}$ ypertonie vaskulären ursprungs, plexogene pulmonale arteriopathie und der appetizügler aminorex:
nachlese zu einer epidemie. Schweiz M ed Wochenschr 1985;115:782-9. $19 \mathrm{Kay} J \mathrm{M}$, Smith P, Heath D. Aminorex and the pulmonary circulation. 
$20 \mathrm{G}$ ahl K, Greiser E. Erfahrungern einer klinisch-epidemiologischen studie zum problem der primär vaskulären pulmonalen Hypertonie. Greiser E. Epidemiologische Úntersuchungen zum Zusammenhan Hypertonie internist 1973:14:437-42. $\mathrm{K}$ raupp VO. Tierexperimentelle untersuchungen zur Ätiologie der 23 pyrmaren pulmonalen Hypertension. Wen Z Inn M ed 1969;50.493-6. ayrne-Quinn $E, G$ rover RF. Aminorex (M enocil) and amphetamine:
acute and chronic effects on pulmonary and systemic haemodynamics in the calf. Thorax 1972;27:127-31. Silter KU, Siegfriedt A. The
ullmann, Parwaresch M R Sattler M, Seiler

Lullmann, Parwaresch
effects of anorectic of rat lungs after chronic administration. A rzneimittel-f orschung 1972 22:2096-9.
Voelkel N F, Clarke WR, Higenbottam T. Obesity, dexfenfluramine, and
pulmonary hypertension: a lesson not learned? Am J Respir Crit Care pulmonary hyperten
$M$ ed $1997 ; 155: 786-8$

26 H erve P, D rouet L, D osquet C, Launay J-M, Rain B, Simonneau G et al. Primary pulmonary hypertension in a patient with a familia

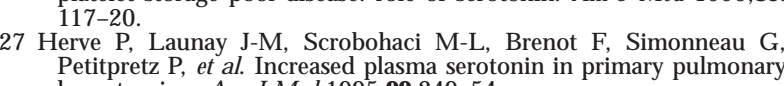
Petitpretz $P$, et al. Increased plasma serotonin in primary pulmonary
hypertension. Am I M ed 1995:99.249-54.
28 M CG oon M D, Vanhoutte PM. Aggregating platelets contract isolated canine pulmonary arteries by releasing 5-hydroxytryptamine. J Clin Invest 1984; 74:828-33.
Lee S-L, Wang WW, Lanzillo JJ, F anburg BL. Serotonin produces both hyperplasia and hypertrophy of bovine pulmonary artery smooth
muscle cells in culture. A m I Physiol $\mathbf{2 6 6}(\mathrm{L}$ ung Cell M ol Physiol 10): 1994:L46-52. WW, Fanburg BL. N itroprusside inhibits serotonininduced mitogenesis and tyrosine phosphorylation of smooth muscle cells. A m I Physiol 270(Lung Cell M ol Physiol 14): 1996:L $362-7$.
Pitt BR, Weng W, Steve AR, Blakely RD, Reynolds I, D avies P. Serotonin increased DNA synthesisin rat proximal and distal pulmonary vascular 10): 1994 :L $178-86$.
Abenhaim L, Rich S, Benichou J, Begaud B. Letter to the editor. N Engl J M ed 1997;336:512-3. $3 \mathrm{~N}$ aeije $R$, Wauthy $P$, M aggiorini M, Leeman M, D elcroix M . Effects of

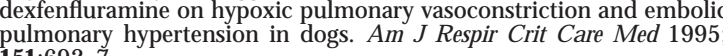
$\mathrm{N}$ ational Task Force on the Prevention and Treatment of Obesity. Long-term pharmacotherapy in the management of obesity. J A M A

5 Voelkel N. D rug-induced pulmonary hypertension: must history repeat 